\title{
Task-based Cycle in Reading Comprehension Classes
}

\author{
Naemeh Nahavandi (Corresponding author) \\ Department of Language and Humanities Education \\ Faculty of Educational Studies \\ Universiti Putra Malaysia \\ Tel: (+98) 9379173225 E-mail: naemeh.nahavandi@gmail.com \\ Jayakaran Mukundan \\ Department of Language and Humanities Education \\ Faculty of Educational Studies \\ Universiti Putra Malaysia \\ Tel: (+60) 012- 2099717 Fax: 603-89435386 \\ E-mails: jaya@educ.upm.edu.my; jayakaranmukundan@yahoo.com
}

Received: 11-11- 2012

Accepted: 11-01- 2013

Published: 01-03- 2013

doi:10.7575/aiac.ijalel.v.2n.2p.107

URL: http://dx.doi.org/10.7575/aiac.ijalel.v.2n.2p.107

\begin{abstract}
This study has investigated the effect of task-based cycle on Iranian Elementary EFL learners' reading comprehension. In order to accomplish the research, two intact classes, including 84 engineering EFL learners (studying pre-university course) were chosen in Tabriz Azad University. An experimental method of research was employed. The experimental group was taught according to the elements of task-based cycle proposed by Willis \& Willis, (2007). The control group didn't receive such treatment. After eight sessions (3 months), a post-test was given. The analysis of the obtained data, carried out through t-test, revealed a significant difference between control and experimental group on the dependent variable, reading comprehension. However, gender didn't affect reading comprehension significantly. The results of the present study may have pedagogical implications for instruction and curriculum development.
\end{abstract}

Keywords: task-based cycle, EFL learners, reading comprehension

\section{Introduction}

Many areas of education are undergoing changes in the way teaching and learning is perceived. Structural- syllabus approaches and teacher centered classes are giving way to more practical and flexible approaches and student-centered classes. In this paradigm shift, the field of second and foreign language teaching is not an exception. One of the areas which came under paradigm shift is the traditional PPP (Present Practice Produce) method of teaching English which has been replaced by CLT (Communicative Language Teaching) and Task-Based Language Teaching is an offshoot of CLT (Nahavandi \& Mukundan, 2012).

The emergence of task-based syllabuses in the mid 1980s has coincided with a significant amount of Second Language Acquisition (SLA) research (Ellis 2006; Nunan 1989; Prabhu 1987; Skehan 1996; Swan 2005; Willis \& Willis 2007) on the kinds of negotiation that learners undertake during tasks and on the types of tasks which appear to facilitate best negotiation for meaning. The reason for the interest in task-based approaches to language teaching and learning is a wide-spread interest in the functional views of language and communicative language teaching. Task- based learning (TBL) is supported by the process-oriented view of language learning where meaningful communicative tasks enhance 12 learning.

Since the 1980s a considerable amount of course books have been produced which describe themselves as 'communicative', irrespective of whether or not they are based on communicative principles. In addition the label taskbased may have been exploited in the same way. The motto of using task-based approach is approximately a common feature of most language schools and universities in Iran. But in reality most teachers are not even familiar with the basic concepts of TBL (Nahavandi 2013; Nahavandi \& Mukundan 2012). Furthermore, during the past decades there has been a good number of studies concerning the importance of TBL. However, few studies on task work are classroom-based; most are carried out under pseudo-laboratory conditions which might be too far from the real conditions of a class. As Buyukkarci (2009) claims "there are not many published examples of complete language programs which claim that they are totally based on formulations of task-based language teaching. The literature contains mainly descriptions of examples of task-based activities" (p. 314).

\section{Literature Review}

Allwright (1981) was one of the first who argued for the effectiveness of tasks as a stimulus to learning. He questioned the need for language instruction and emphasized the need for language use. One of the well-documented published researches on task-based language learning is Prabhu's procedural syllabus. In 1979, Prabhu started a five-year project 
in Bangalore with a small number of elementary and secondary English classes. One purpose of the Bangalore project was to develop a methodology in a "sustained teaching" environment. Prabhu's view challenged the "Structural-OralSituational" (SOS) methods, which may be viewed as analogous to the Audio lingual method popular in high schools and colleges since 1960s. An underling principle of both SOS and Audio lingual methodologies is that language learning can be taught through direct instruction. A major difference between SOS and the theory of grammar are observed through repetition of artificially constructed language while in communicative competence both fluency and accuracy are taken care, though 'meaning' is of primary significance. Prabhu (1987) argued that, in the context of this school -based project, the most effective teaching took place through activities that pushed the cognitive boundaries of the students. Prabhu believed that there are four types of classroom activities: rule-focused; form-focused; meaningful and meaning-focused. His method favored "meaning focused activities" to the exclusion of the other three types. Prabhu's rejection of any "form-focused activities" relies on his assumption that learners can internalize some system of grammar through focusing on meaning. He believes that acquisition of a linguistic structure is not an instant, one-step procedure and agrees with Krashen that language form is acquired subconsciously trough internal system of abstract rules and principles, when the learners' attention is focused on meaning, i.e., task completion rather than on language. But some theoreticians have challenged his view: learners may impose their own syllabus on what we teach them, focusing on form when we desire them to focus on meaning.

\subsection{Task, Task-based Learning \& Task-based Teaching}

Carter and Nunan (2001) define task as "an activity in the classroom which involves language use to achieve a communicative purpose" (p. 227). For Ellis (2003) "tasks are activities that call for primarily meaning focused language use" (p.3). Nunan (1999) makes a distinction among task, exercise and activity. For Nunan, task is a communicative act which usually does not have a restrictive focus on a single grammatical structure. An exercise usually has a restrictive focus on a single language element and has a linguistic outcome. An activity has a restrictive focus on one or more language items, but also has a communicative outcome.

TBL grows out of the more general notion of CLT. After Hyme's notions of communicative competence, paying attention to language and the need to make language relevant to students' needs and providing opportunities for language use in the classroom was considered very important. According to Richards and Rodgers (2001), the sharing principles of CLT and Task - Based Language Teaching (TBLT) are:

- Activities which involve real communication are vital for language learning.

- Activities in which language is used for promoting meaningful tasks promote learning.

- Language which is meaningful to the learner supports the learning process.

TBLT bases arguments for an analytic syllabus on what is known about the processes involved in second language learning, on the findings of second language classroom research and on principles of course design. For Mckinnon and Rigby (2004), if we can make language in the classroom meaningful therefore memorable, students can process language which is being learned or recycled more naturally. This is what TBL exactly offers the students an opportunity to do. In TBL, task is the primary focus of classroom activity and language is the instrument which the students use to complete it. TBL considers language use as the driving force in language learning, with the task central to both syllabus planning and methodology.

According to Richards and Rodgers (2001), in TBLT language learning depends on immersing students not only in comprehensible input but also in tasks which require them to negotiate meaning and engage in naturalistic and meaningful communication. For Long and Crooks (1992), the basic rationale for TBLT derives from descriptive and experimental studies comparing tutored and naturalistic learning. Task-based approaches represent how something is done. According to Breen (1987, cited in Foley 1991), task-based approaches organize and present what is to be achieved through teaching and learning in terms of how a learner might engage his or her communicative competence in undertaking a range of tasks. For Ellis (2003), various approaches to task-based teaching reflect the issues such as "the role of meaning-based activity, the need for more learners-centered curricula, the importance of affective factors, the contribution of learner-training, and the need for some focus-on-form. Task-based pedagogy provides a way of addressing these various concerns and for this reason alone it is attracting increasing attention" (p. 33). Richards and Rodgers (2001) believe that in TBLT tasks provide both the input and output processing necessary for language acquisition and task activity and achievement are motivational. The underlying principle in TBLT is that having learners perform tasks will help them to develop knowledge and skill in the second language in accordance with the way their own language learning mechanisms work. Tasks function as "devices for creating the conditions required for language acquisition' (Ellis 2002, p. 226).

$\mathrm{Ki}$ (2000) summarizes the potential advantage of the task-based approach as follows: a) A task-based lesson increases the learners' motivation, because it gives them an active role in participation and creation. b) More opportunities are provided for the students to externalize their thinking through their actions by using task-based lesson. c) It lets students use the knowledge they have learned and apply it productively in the task context. d) The practical experience can help learners to appreciate why certain academic questions are important and it can lead to the development of a further academic discourse. e) The task usually requires the creation of some objects as outcome. So it can lead to a shared focus where students can work together. In the ongoing process, different participants, including peer learners in the team and the tutor can project different views on the same situation and meaningful discussion on the matter can be developed. The task will usually generate objects that are open to cross-group evaluation. In other words, the students 
can present their own product and/or evaluate others. Everybody can take part in evaluating the strengths and weaknesses of the work that is generated within the classroom community. This will induce reflection and also critical awareness in students can be developed.

\subsection{Task Cycle}

Willis (1994, cited in Nahavandi \& Mukundan 2012; Willis \& Willis 2007) states that there is a six stage cycle in taskbased teaching: The first stage is introduction to both topic and task, in which the teacher helps the students in understanding the objectives of the task. For Bowen (2004) in this stage students take part in activities that either helps them to recall words or phrases which will be useful during the performance of the task. The second stage is the task itself. Students work in pairs or groups using whatever language resources they have got in expressing themselves. Teacher encourages them but there is no correction. Fluency and getting things done- the purpose is emphasized. The third stage is called planning. Students spend some time on putting together in spoken or written form a report on what they did and what conclusions they reached. If it is required, the teacher can help with language here, with the emphasis on ability to communicate the results. The fourth stage is called reporting where the teacher organizes feedback, with the groups reporting to the class, either orally or in writing their results. Again, there is no overt correction. The fifth stage is language focus and practice in which the teacher sets up a language focus task, which draws attention to one or more of the following: a) language which students could have used but they did not use, b) language they used but not as well as they might have used, c) any other language that is related to the topic and task which the teacher considers important and wishes to focus on. This stage can include drills, dialogues or typical activities from the practice stage of Present Produce Practice (PPP). In all cases, the goal is to focus students' attention on key language points. The last stage is the parallel task where the students have a chance to try out the task again, but with different materials, which will necessitate the same kinds of language.

\subsection{Research Questions}

1. Does applying task-based cycle in reading classes affect Iranian EFL learners' reading comprehension?

2. Is there a significant difference between male and female learners in the experimental group in their reading comprehension?

\section{Methodology}

\subsection{Design of the study}

The present study employed an experimental design with pretest, treatment, and posttest design. The participants completed the pretest and were randomly assigned to the experimental and control groups. The participants in the both group completed treatment tasks according to their group designation. The post-test was administered one week after the last treatment session.

\subsection{Participants}

The participants of the present study were 91elementary learners in Azad university of Tabriz, Iran registering in preuniversity English course during October 2012. Both classes were mixed classes including male and female students with the age range of 18 to 25 . All participants were assigned to one of two treatment groups based on the class they were enrolled in. In order to make sure that the participants were all at the same level of proficiency, a pretest was administered. The results of the pre test indicated that there was no significant difference between groups in the pre test. Therefore, participants in class $1(\mathrm{~N}=44)$ were assigned to a control group, and participants in class $2(\mathrm{~N}=47)$ to experimental group. This study was conducted with the consent of participation with an indication of the general purposes and procedures of the study. But it is worthy of noting that, nine students who were not present in all treatment sessions and posttest were eliminated from the population pool. Therefore the results of only 84 students class $1(\mathrm{~N}=$ $43)$, and class $2(\mathrm{~N}=41)$ are reported in the present study.

\subsection{Instruments}

\subsubsection{Demographical Information}

To obtain necessary demographical information about the subjects like, age, gender, educational level, and major of study, first a demographical questionnaire was distributed among the subjects in the second session together with the pretest.

\subsubsection{Reading Texts}

Proficiency test: In order to measure students' reading comprehension both in pretest and posttest six reading excerpts from PET (Preliminary English Test) were chosen (three for pretest and three for posttest). Every reading had 7 reading comprehension questions; in sum both pretest and posttest had 21 questions. For treatment, eight reading comprehension passages consisting nearly 270 to 300 words from Active skills for reading (Intro) were selected. The participants in the experimental groups were taught based on the elements of task-based cycle proposed by Willis \& Willis (2007). However, participants in the control group read the same texts without such treatment.

\subsection{Data collection}

\subsubsection{Procedure}

The experimental part of the study took place over three months. The classes for pre- university course are applied once a week lasting for 90 minutes for 14 weeks. The study was conducted from second week as there is a week interval for 
adding and dropping the courses. Thus, second week of the new semester, participation agreement for the experiment was obtained together with the level test. It is worthy of noting that the reading texts were obtained from Active reading (Intro). The Third week first treatment was administered. Treatment was organized based on pre-task cycle, task cycle and post-task cycle. The first stage was the pre-task stage (preparation). Here there is an introduction to topic and task. The teacher explored the topic with the class, tried to highlight useful words and phrases, and helped learners understand task instructions. In other words, students took part in activities that either helped them to recall words or phrases which would be useful during the performance of the main task. The second stage was the task cycle or follow up activities. Here, students did the task, in pairs or small groups. Teacher monitored from distance, however, there was no correction. As Willis \& Willis (2007) claim, this situation has a "private" feel, so students feel free to experiment and mistakes don't matter. Then, they reported to the whole class how they did the task and what conclusions they reached. This stage is called planning and report stage. As Willis \& Willis (2007) claim, since the report stage is public, accuracy of students counts in this stage. Thus, the teacher stands by to give language advice. In other words, in this stage, teacher acts as a chairperson, and then comments on the content of the reports. The final stage was post-task cycle or follow up activities, which is also known as analysis stage, during which students noticed interesting features or patterns in the text. The teacher conducted practice of new words, phrases, and patterns occurring in the text. Meanwhile, the control group received no such treatment. They read their readings alone or with a partner, and then they listened to the teacher or to the more capable students or volunteers to read it for the whole class. They asked the meaning of the words that they did not know and finally answered the teacher's and book's comprehension questions. All eight treatment sessions incorporated the exact same method as the first treatment but with a different text. Each treatment session lasted for about 90 minutes. The 10th week a post-test was administered, lasting 45 minutes.

\subsection{Data Analysis}

In this study, the independent variable was task-based cycle and the dependent variable was the participants' reading comprehension. The design to carry out this study was experimental, with a pretest, different treatments for experimental and control groups, as well as a post-test. To answer the research questions regarding the difference between two different instructions, independent and paired t-test was used.

\section{Results of the study}

\subsection{Demographical information of the Learners}

The obtained results in the present study were analyzed by SPSS version (20). From 84 students, 54 (64.3) were male, and 30 (35.7) were females. The average mean of age was 19.38. The minimum age was 18 , and maximum age was 25 .

\subsection{Test of Normality}

To test the normality of the distribution, a Kolmogorov-Smirnov test was run. The results indicated that distribution of the scores at both levels of pretest, and posttest was normal (Significant level $>0 / 05$ ).

Table 1. One-Sample Kolmogorov-Smirnov Test

\begin{tabular}{llll}
\hline & $\mathrm{N}$ & Kolmogorov-Smirnov Z & Asymp. Sig. (2-tailed) \\
\hline pre & 84 & .974 & .299 \\
\hline post & 84 & .855 & .457 \\
\hline
\end{tabular}

\subsection{Comparing pretests in both groups}

Based on the obtained results parametric statistics was used. First mean score and SD of both groups were calculated.

Table 2. Results of independent t-test for pretest in both groups

\begin{tabular}{|c|c|c|c|c|c|c|c|c|c|}
\hline & \multirow[t]{2}{*}{ group } & \multirow[t]{2}{*}{$\mathrm{N}$} & \multirow[t]{2}{*}{ Mean } & \multirow{2}{*}{$\begin{array}{c}\text { Std. } \\
\text { Deviation }\end{array}$} & \multicolumn{2}{|c|}{$\begin{array}{c}\text { Levene's Test } \\
\text { for Equality of } \\
\text { Variances }\end{array}$} & \multicolumn{3}{|c|}{ t-test for Equality of Means } \\
\hline & & & & & $\mathrm{F}$ & Sig. & $\mathrm{t}$ & $\mathrm{df}$ & $\begin{array}{l}\text { Sig. (2- } \\
\text { tailed) }\end{array}$ \\
\hline \multirow[b]{2}{*}{ pre } & control group & 43 & 8.72 & 3.397 & \multirow{2}{*}{.997} & \multirow{2}{*}{.321} & \multirow{2}{*}{-403} & \multirow{2}{*}{82} & \multirow{2}{*}{.688} \\
\hline & $\begin{array}{l}\text { experimental } \\
\text { group }\end{array}$ & 41 & 9.05 & 4.037 & & & & & \\
\hline
\end{tabular}

As can be seen in table 2, mean of control group is 8.72, and experimental group is 9.05. Hence mean score of experimental group is higher than control group Levene Statistic test was run to see whether the difference in mean score in these two groups is significant or not. Based on the significant level of Levene test $0 / 321>0 / 05$, homogeneity of variances is confirmed. As can be seen in table 2 , level of significance is $0 / 688>0 / 05$; therefore, there is no significant difference between the groups in pretest. Therefore, it can be claimed that any measurable changes in the 
posttests is unlikely to be the effect of preexisting differences between the groups and, instead, can be attributed to the different treatments that the these groups experienced.

\subsection{Comparing posttest in both groups}

Table 3. Results of independent t-test for posttest in both groups

\begin{tabular}{|c|c|c|c|c|c|c|c|c|c|}
\hline & \multirow{2}{*}{ group } & \multirow{2}{*}{$\mathrm{N}$} & \multirow{2}{*}{ Mean } & \multirow{2}{*}{$\begin{array}{c}\text { Std. } \\
\text { Deviation }\end{array}$} & \multicolumn{2}{|c|}{$\begin{array}{c}\text { Levene's Test } \\
\text { for Equality of } \\
\text { Variances }\end{array}$} & \multicolumn{3}{|c|}{ t-test for Equality of Means } \\
\hline & & & & & $\mathrm{F}$ & Sig. & $\mathrm{t}$ & df & $\begin{array}{l}\text { Sig. (2- } \\
\text { tailed) }\end{array}$ \\
\hline \multirow[b]{2}{*}{ post } & control group & 43 & 9.28 & 3.528 & \multirow[b]{2}{*}{.241} & \multirow[b]{2}{*}{.625} & \multirow[b]{2}{*}{-2.462} & \multirow[b]{2}{*}{82} & \multirow[b]{2}{*}{.016} \\
\hline & $\begin{array}{l}\text { experimental } \\
\text { group }\end{array}$ & 41 & 11.15 & 3.417 & & & & & \\
\hline
\end{tabular}

To compare post tests in both groups independent t-test was used. As can be seen in table 3, mean of control group is 9.28, and experimental group is 11.15 . The level of significance found to be $0 / 016$. As the level of sig is smaller than $0.05,0.05>0.016$ it can be concluded that there is a significant difference between experimental and control groups in the post test. It means that experimental group significantly outperformed the control group in the post test.

\subsection{Comparing gender differences in both groups}

Table 4. Independent t-test for comparing pretest and post test in both groups

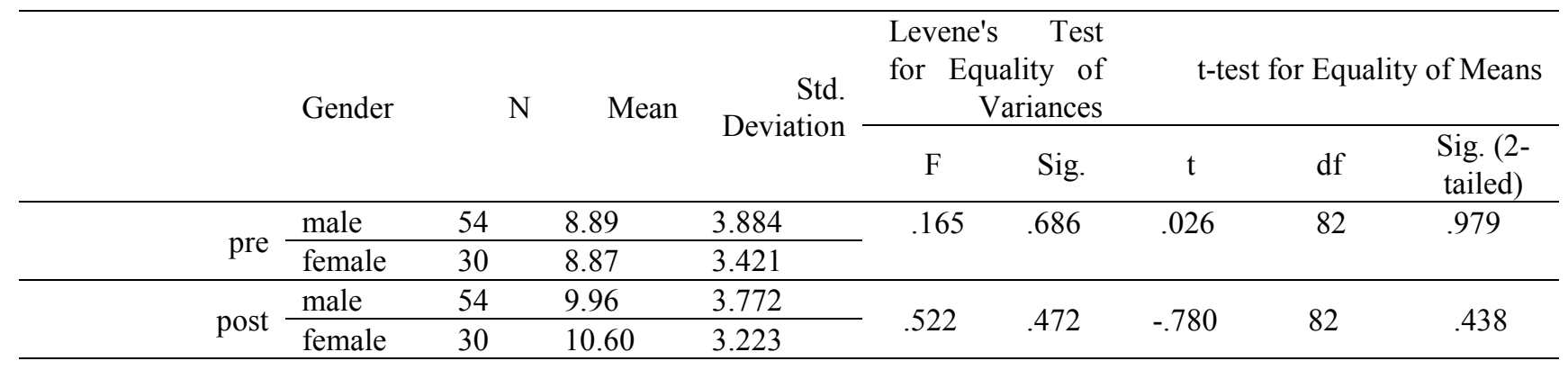

To compare gender difference in both groups independent t-test was used. As table 4 shows, mean of pretest among males is 8.89 and among females is 8.87 and level of significance found to be 0.979 . Because $0.979>0.05$ it can be concluded that there isn't a significant difference between male and female students in the pre test. Furthermore, mean of post test among males is 9.69 and among females is 10.6, and level of significance found to be 0.438 . As level of sig $0.438>0.05$, it can be concluded that there isn't a significant difference between male and female students in the post test.

\subsection{Comparing pre and post tests}

Table 5. Results of paired t-test for comparing pre and post tests

\begin{tabular}{ccccccc}
\hline & $\mathrm{N}$ & Mean & Std. Deviation & $\mathrm{t}$ & df & Sig. (2-tailed) \\
\hline pre & 84 & 8.88 & 3.704 & -3.993 & 83 & .000 \\
\hline post & 84 & 10.19 & 3.579 & & & \\
\hline
\end{tabular}

To compare pre and post tests, paired t-test was used. As table 5 shows, mean of pre test is 8.88 and mean of post test is 10.19 , and level of sig is 0.000 . Considering level of sig which is smaller than 0.05 , it can be concluded that there is a significant difference between post test and pre test. Post test is significantly higher than pre test.

\subsection{Comparing pre and post test between both groups}

Table 6. Paired t-test for comparing pre and post test

\begin{tabular}{|c|c|c|c|c|c|c|c|}
\hline & & $\mathrm{N}$ & Mean & Std. Deviation & $\mathrm{t}$ & df & Sig.(2-tailed) \\
\hline \multirow[t]{2}{*}{ control group } & pre & 43 & 8.72 & 3.397 & \multirow[t]{2}{*}{-1.431} & \multirow[t]{2}{*}{42} & \multirow[t]{2}{*}{.160} \\
\hline & post & 43 & 9.28 & 3.528 & & & \\
\hline \multirow[t]{2}{*}{ experimental group } & pre & 41 & 9.05 & 4.037 & \multirow[t]{2}{*}{-4.117} & \multirow[t]{2}{*}{40} & \multirow[t]{2}{*}{.000} \\
\hline & post & 41 & 11.15 & 3.417 & & & \\
\hline
\end{tabular}


To compare pre and post tests, paired sample t-test was used. As table 6 shows, mean of control group is 8.27 and post test is 9.28 , and level of sig is 0.16 . As level of sig is bigger than 0.5 , it can be concluded that there isn't a significant difference between pre and post test in the control group. However, in experimental group, mean of pre test is 9.05 and post test is 11.15 , and level of sig is 0.000 . As the level of sig is smaller than 0.05 it can be concluded that there is a significant difference between pre test and post test in the experimental group.

\section{Discussion \& Conclusion}

According to Rivers (1981), until recently there has been great emphasis on listening and speaking skills. As a result, forging language teacher are sometimes accused of wishing to produce "fluent chatterboxes who can speak the new language but have nothing worthwhile to say because they have never been given the opportunity to share the thinking of the great minds of another culture and so to widen the horizons of their knowledge and understanding" (Rivers, 1981, p. 259). For lots of reasons reading is the most important activity in any language class. Because it is not only a source of information and a pleasurable activity, but also a means of consolidating and extending one's knowledge of the world (Nahavandi \& Mukundan 2012). Because of its great importance as a cognitive process reading needs careful attention in language classes. Because it is a communicative act between the reader and writer it requires an interactive and process-oriented methodology.

Although teachers try hard to teach reading passages successfully in their classes, there is always a mismatch between their teaching and students' learning. Most of teachers are dissatisfied with the outcome. Students are bored with reading classes because they see no maneuver of their own initiation. Although TBLT is said to be used in EFL language classes in educational settings in Iran, most teachers are not even familiar with its concepts (Nahavandi \& Mukundan 2012). Now that the value of interaction and the importance of TBLT in EFL classes are emphasized, applying principles of TBL in EFL classes seems necessary. So for improving students' reading comprehension such an atmosphere should be created in the classes that students enjoy their classes and learn the responsibility for their own learning. Using taskbased activities in which every student takes part in understanding, evaluating, discussing, problem-solving, negotiating meaning processes can be effective in meeting the requirements of learner-centered classes (Nahavandi, 2011). The learners and their world view that is shared with each other in reading classes during performing task-based activities are of great importance in TBLT. When the responsibility of learning and teaching shifts from teacher to the learner, learners themselves take the responsibility for their own learning. They interact with each other in pairs discussing, evaluating, agreeing, disagreeing, exchanging personal information, solving problems all of which are process-oriented and which are of great importance for challenging students' brains.

The results of the present study showed that applying the elements of task-based cycle affected students' reading comprehension positively. Therefore, the results of the study may have some pedagogical implications for language teachers. Applying TBLT in reading classes and letting the students be responsible for their own learning and providing lots of opportunities for pair work and group work in the class will create an active classroom atmosphere where all the students engage in the process of their own learning task. In TBLT classes the responsibility of teacher shifts from "knowledge provider" to use Widdowson's words to," facilitator of students' learning" or to put it in other words to function as an authoritative rather than an authoritarian (Nahavandi \& Mukundan 2012; Nahavandi \& Mukundan 2013a; Nahavandi \& Mukundan 2013b). Furthermore, the results of the present study may benefit EFL learners. Most learners are unaware of their capabilities for learning. They believe that teachers are the sole origin of information in whom they should trust completely. Although the concept of TBLT has captured most EFL institutions and universities of Iran, learners prefer individualistic learning which allows them to sit silently on their chairs and cover the readings alone, and to answer the books' questions. So it can be claimed that using TBL in reading classes make reading classes a lively and friendly atmosphere where every student tries hard to solve the problem and share his/her ideas with group member. Finally, the results of the present study may benefit syllabus designers, teacher trainers and other interested researchers. Last but not least, it is hoped that the present research may encourage further research in the area of task- based teaching and learning in Iranian EFL context by other interested researchers.

\section{References}

Allwright, R. L. (1981). What do we want teaching materials for? 1. ELT Journal, 36(1), 5-18.

Bowen, T., (2004). Task-based Learning. Retrieved from file: www.onestopenglish.com/ News/Magszine/Archive/taskbased.htm-15k.

Buyukkarc, K. (2009). A CRITICAL ANALYSIS OF TASK-BASED LEARNING. Kastamonu Education Journal, 17(1), 313-320.

Ellis, R. (2002). The Evaluation of Communicative Tasks, in B. Tomlinson (Ed.), Materials Development in Language Teaching, Cambridge: Cambridge University Press, 217-238.

Ellis, R. (2003). Task-based Language Learning and Teaching. Oxford: Oxford University Press.

Ellis, R. (2006). The methodology of task-based teaching. Asian EFL Journal, 8(3), 1-17.

Foley, J. (1991). A Psycholinguistic Framework for Task-based Approaches to Language Teaching. Applied Linguistics. 12, 62-75. 
Ki, W. W. (2000). ICT Applications in Task-Based Learning. In N. Law and et. al. Changing Classrooms \& Changing Schools: A Study of Good Practices in Using ICT in Hong Kong Schools (pp: 79-91). Hong Kong, Friendship Printing Co., Ltd.

Long, M. H., \& Crooks, J. (1992). Three Approaches to Task-Based Syllabus Design. TESOL QUARTERLY, 26(1), 127-144.

Mckinnon, M. \& Rigby, N. (2004). Task-based Learning. Macmillan publishers Ltd.

Nahavandi, N. (2011). The effect of task-based activities on EFL learners' reading comprehension. In Mukundan, J., Nimehchisalem, V., Menon, S., Jin, Y.J., Roslim, R., Leong, A., Mohamad, A. \& Philip, A. (Eds.). (2011). ELT Matters 5 (pp.56-69). Petalingjaya, Malaysia: Galaxy.

Nahavandi, N. (2013). Task-based activities in reading comprehension classes: Task-based language teaching \& learning. LAP Lambert Academic Publishing.

Nahavandi , N. \& Mukundan, J. (2012). Task-based language teaching from teachers' perspective. International Journal of Applied Linguistics \& English Literature, 1 (6), 115-121. doi:10.7575/ijalel.v.1n.6p.115, URL: http://dx.doi.org/10.7575/ijalel.v.1n.6p.115.

Nahavandi , N. \& Mukundan, J. (2013a). Foreign Language Learning Anxiety among Iranian EFL learners Along Gender \& Different Proficiency Levels. Language in India. 13(1), 133-161.

Nahavandi , N. \& Mukundan, J. (2013b). Iranian EFL Engineering Students' Motivational Orientations towards English Language Learning along Gender and Further Education in Language Institutes. International Journal of Linguistics, 5(1), doi:10.5296/ijl.v5i1.2684.

Nunan, D. (1989). Designing Tasks for the Communicative Classroom, Cambridge: Cambridge University Press.

Nunan, D. (1991). Communicative Tasks and the Language Curriculum, TESOL QUARTERLY, 15(2), 279-295.

Nunan, D. (2001). Aspects of Task-Based Syllabus Design. Retrieved from file: www.telus.net/linguistic issues/syllabus design.html-20-k.

Prabhu, N.S. (1987). Second Language Pedagogy, Oxford: Oxford University Press.

Richards, J.C., \& Rodgers, S. (2001). Approaches and Methods in Language Teaching ( $2^{\text {nd }}$ ed), Cambridge: Cambridge University Press.

Rivers, W. M. (1981). Teaching Foreign Language Skills ( $2^{\text {nd }}$ ed), Chicago: The University of Chicago Press.

Skehan, P. (1996). A Framework for Implementation of Task-based Instruction, Applied Linguistics, 17(1), Oxford University Press, 38-59.

Swan, M. (2005). Legislation by Hypothesis: The Case of Task-Based Instruction. Applied Linguistics 26 (3), 376-401.

Willis, D., \& Willis, J. (2007). Doing task-based teaching. Oxford: Oxford University Press. 